\title{
Lapunk olvasottsági eredményei
}

\author{
The journal's popularity
}

doi: 10.24365/ef.v61i3.631

Folyóiratunk népszerűsége stabilan növekszik, ami a lapban megjelenő cikkek szakmai értékét mutatja és alátámasztja, hogy a szakemberek, olvasók számára érdekes és hasznos információkat közvetítünk.

Ezúttal - technikai okokból - a korábbiaktól eltérően, az olvasottsági statisztikákat vizsgálva mutatjuk be a lap iránti érdeklődést. Az alábbi ábrán 2020 nyári hónapjainak olvasottsági adatai láthatók, mind az absztraktok, mint a teljes cikkek megtekintésére vonatkozóan.

Az adatok azt mutatják, hogy nyáron növekedett az olvasási kedv, és augusztusban volt a legmagasabb az olvasói érdeklődés. Mindhárom hónapban közel kétszer annyian olvasták el a közlemények összefoglalóit, mint akik olvasásra a teljes szöveget töltötték le.

A második oldalon látható táblázatban a megszokott formában mutatjuk meg a TOP 10-es cikkeket, vagyis a tíz leggyakrabban megtekintett összefoglalót, valamint a legtöbbször megnyitott teljes közleményt 2016 óta számítva, illetve az „érdekességi mutató” alapján a publikálásuk óta eltelt idő alatt a legtöbbet olvasott írásokat.

Írják meg hozzászólásaikat, javaslataikat a cikkekhez bejelentkezés után a weboldalon, és kövessék a lapot a facebook-on is.

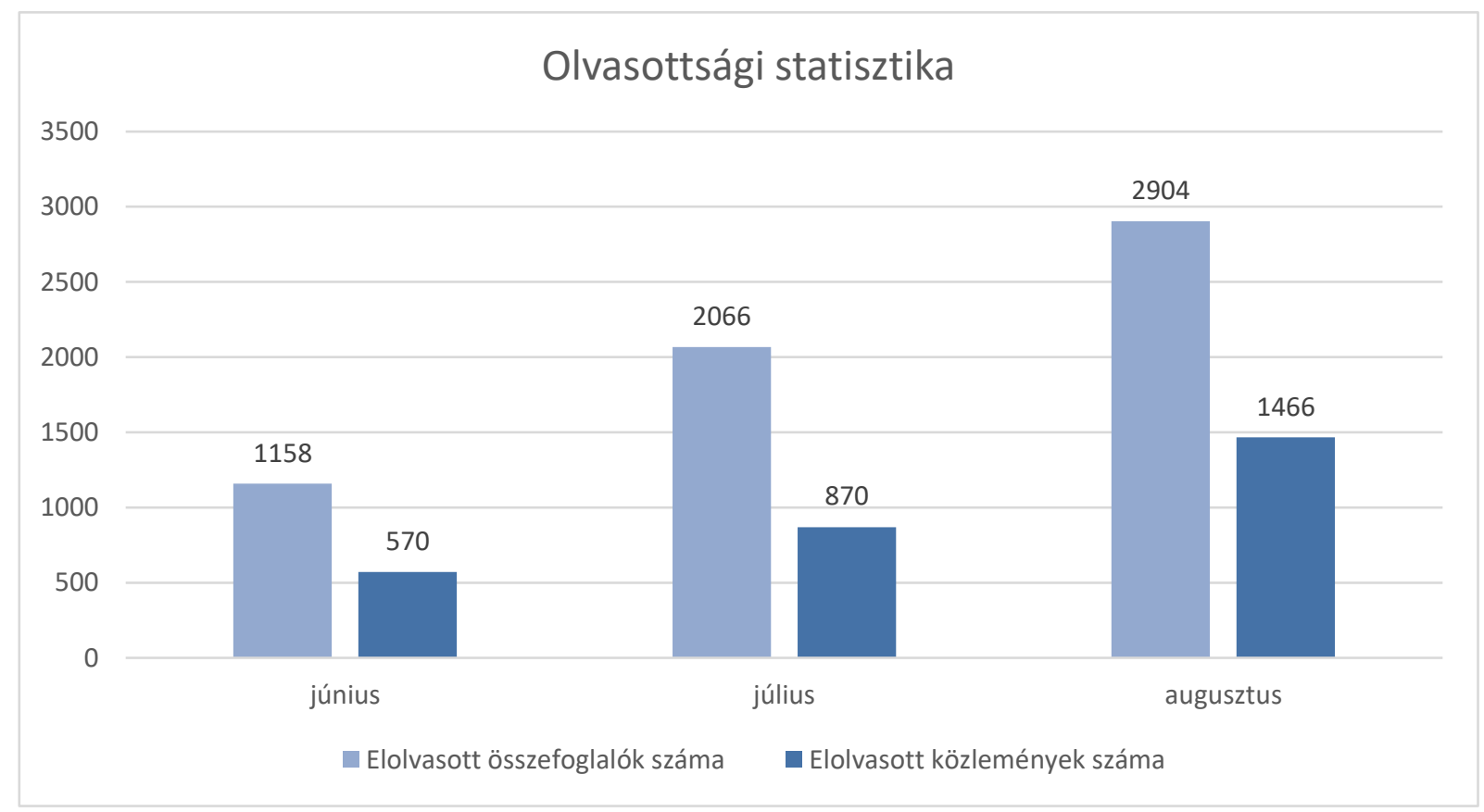




\begin{tabular}{|c|c|c|c|}
\hline $\begin{array}{l}\text { Megtekinté- } \\
\text { sek száma }\end{array}$ & Közlemény címe & Szerzők & $\begin{array}{l}\text { Lap- } \\
\text { szám }\end{array}$ \\
\hline \multicolumn{4}{|c|}{ ÖSSZEFOGLALÓ } \\
\hline 1156 & Egészséges életmóddal kapcsolatos kutatások a hazai iskolákban & Járomi É, Szilágyi K, Vitrai J & 2016/1 \\
\hline 933 & Hazai egészség-pillanatkép, 2017 & Vitrai J, Bakacs M, Varsányi P & $2017 / 4$ \\
\hline 909 & A kortársbántalmazás (bullying) mint népegészségügyi probléma & Várnai D, Zsíros E, Németh Á & $2016 / 4$ \\
\hline 865 & Az egészségmúveltség definíciói & Csimadia P & $2016 / 3$ \\
\hline 804 & A magyarországi egészségértés nemzetközi összehasonlításban & Koltai J, Kun E & $2016 / 3$ \\
\hline 748 & $\begin{array}{l}\text { Kortárs egészségfejlesztési programok gyermekek és fiatalok körében a hazai és a } \\
\text { nemzetközi szakirodalom tükrében - Szisztematikus áttekintés }\end{array}$ & Lukács-Jakab Á et al. & 2018/1 \\
\hline 740 & A fizikai aktivitás, mint egészségbefektetés & Gabnai Z et al. & 2019/1 \\
\hline 734 & Családközpontúság és ágazatközi együttmúködés a kora gyermekkori intervencióban & Kereki J, Kispéter L-né & $2018 / 5$ \\
\hline 673 & Egészségfejlesztő program középiskolások körében - Az alapállapot felmérés eredményei & Pénzes G, Bíró É & $2018 / 4$ \\
\hline 649 & $\begin{array}{l}\text { Az egészségügyi ellátáshoz való hozzáférés területi egyenlőtlenségeinek vizsgálata az akut } \\
\text { miokardiális infarktus okozta halálozás adatainak felhasználásával }\end{array}$ & Uzzoli A, Vitrai J, Tóth G & $2017 / 3$ \\
\hline \multicolumn{4}{|c|}{ TELES KÖZLEMÉNY } \\
\hline 3675 & A csecsemőkori allergia-megelőzés korszerú irányelvei és lehetőségei & Réthy A & $2017 / 1$ \\
\hline 2009 & Egészségfejlesztési Irodák hálózata & Bezzegh P & 2016/1 \\
\hline 1627 & Egészséges életmóddal kapcsolatos kutatások a hazai iskolákban & Járomi É, Szilágyi K, Vitrai J & $2016 / 1$ \\
\hline 1256 & A fizikai aktivitás, mint egészségbefektetés & Gabnai Z et al. & 20191 \\
\hline 1196 & Magyarország népegészségügyi rendszere és egészségfejlesztéssel foglalkozó szervezetei & Túri G et al. & $2018 / 2$ \\
\hline 1126 & $\begin{array}{l}\text { Energiaital fogyasztási szokások és egészségtudatosság a felsőfokú képzésben résztvevő } \\
\text { hallgatók körében }\end{array}$ & Dojcsákné Kiss-Tóth É, Kiss-Tóth E & $2018 / 4$ \\
\hline 1052 & Hazai egészség-pillanatkép, 2017 & Vitrai J, Bakacs M,Varsányi P & $2017 / 4$ \\
\hline 757 & $\begin{array}{l}\text { Megjelent az Iskoláskorú gyermekek egészségmagatartása kutatás legújabb } \\
\text { felmérésének nemzetközi jelentése }\end{array}$ & Németh Á & 2016/1 \\
\hline 711 & OKOSTÁNYÉR - új táplálkozási ajánlás a hazai felnőtt lakosság számára & Szücs Zs & $2016 / 4$ \\
\hline 684 & A magyarországi egészségértés nemzetközi összehasonlításban & Koltai J, Kun E & $2016 / 3$ \\
\hline \multicolumn{4}{|c|}{ "ÉRDEKESSÉG" } \\
\hline 2,92 & A csecsemőkori allergia-megelőzés korszerú irányelvei és lehetőségei & Réthy A & $2017 / 1$ \\
\hline 2,30 & A fizikai aktivitás, mint egészségbefektetés & Gabnai Z et al. & 2019/1 \\
\hline 1,59 & $\begin{array}{l}\text { Energiaital fogyaszztási szokások és egészségtudatosság a felsőfokú képzésben résztvevő } \\
\text { hallgatók körében }\end{array}$ & Dojcsákné Kiss-Tóth É, Kiss-Tóth E & $2018 / 4$ \\
\hline 1,41 & Magyarország népegészségügyi rendszere és egészségfejlesztéssel foglalkozó szervezetei & Túri G et al. & $2018 / 2$ \\
\hline 1,36 & Koronavírusjárvány: Tanulságok az egészségfejlesztési szakemberek számára & szerkesztőség & 2020/1 \\
\hline 1,27 & Egészségfejlesztési Irodák hálózata & Bezzegh P & $2016 / 1$ \\
\hline 1,06 & Hazai egészség-pillanatkép, 2017 & Vitrai J, Bakacs M, Varsányi P & $2017 / 4$ \\
\hline 1,05 & Krónikus betegségek előfordulásának gyakorisága Nyíregyháza felnőtt lakossága körében & Törő K et al. & $2019 / 5$ \\
\hline 1,03 & Egészséges életmóddal kapcsolatos kutatások a hazai iskolákban & Járomi É, Szilágyi K, Vitrai J & $2016 / 1$ \\
\hline 1,02 & Kiskorúak egészségügyi ellátása Magyarországon betegjogi aspektusból & Feith JH & $2018 / 5$ \\
\hline
\end{tabular}

